\title{
Senyawa Alami Bawang Putih Tunggal sebagai Inhibitor LpxC Bakteri Pseudomonas aeruginosa melalui Virtual Screening
}

\author{
Natural Compound of Single Clove Garlic as an Inhibitor LpxC IN Pseudomonas aeruginosa Bacteria \\ through Virtual Screening
}

\author{
Nur Fitriana ${ }^{1}$, Sri Rahayu Lestari $i^{*}$, Betty Lukiati ${ }^{1}$ \\ ${ }^{1}$ Jurusan Biologi, Fakultas Matematika dan Ilmu Pengetahuan Alam, Universitas Negeri Malang
}

DATA NASKAH:

Masuk: 26 Nov 2017

Direviu: 09 Des 2017

Direvisi: 18 Des 2017

Diterima: 25 Jan 2017

\section{*KORESPONDENSI:}

srirahayulestari@um.ac.id atau

nurfitriana769@gmail.com

DOI:

$10.18196 / \mathrm{mm} .180111$

TIPE ARTIKEL:

Penelitian

\begin{abstract}
Abstrak: Pseudomonas aeruginosa merupakan salah satu bakteri Gram negatif penyebab infeksi nosokomial yang memiliki resistensi tinggi terhadap berbagai antibiotik karena adanya lipid A, komponen LPS bersifat toksik pada inang. Sintesis lipid A dimulai dari Kdo 2 -lipid A, difasilitasi oleh enzim LpxC. Enzim LpxC merupakan target pengembangan antibiotik karena adanya kofaktor $\mathrm{Zn}^{2+}$. Bawang putih tunggal merupakan herbal potensial pengganti antibiotik sintetis. Alliin, Allicin dan Ajoene yang terkandung dalam bawang putih tunggal memiliki aktivitas antibakteri. Penelitian ini bertujuan memprediksi potensi senyawa organosulfur bawang putih tunggal sebagai agen antibakteri melalui virtual screening menggunakan metode molecular docking. Metode yang dilakukan adalah memprediksi potensi senyawa organosulfur menggunakan web server PASS dan melakukan docking untuk mengetahui interaksi ligan-protein target. Hasil penelitian menunjukkan, senyawa organosulfur berpotensi sebagai antibakteri, antibiotik, dan immunomodulator. Aktivitas antibakteri terbaik ditunjukkan oleh senyawa Alliin dengan nilai afinitas pengikatan $-5,2 \mathrm{kkal} / \mathrm{mol}$. Semua senyawa organosulfur memiliki sisi aktif yang sama dengan kontrol (Ciprofloxacin dan Imipenem) pada enzim LpxC. Sisi aktif ditunjukkan dengan adanya residu asam amino (Ser295, Val182, dan Tyr 296) yang berikatan dengan ikatan hidrogen dan interaksi hidrofobik (Phe152, Phe181, Gly85, Phe176, Ala84, Val182, Ser180, Ile241, Leu86, Tyr296, Ser295 dan Met297) antara ligan-protein target.
\end{abstract}

Kata kunci: Enzim LpxC; Infeksi Nosokomial; Molecular Docking; Pseudomonas aeruginosa; Senyawa Organosulfur

\footnotetext{
Abstract: Pseudomonas aeruginosa is one of gram-negative bacteria causes nosocomial infection that have high resistance against various antibiotics due to lipid A, LPS are toxic components on the host. Lipid A synthesis starting from Kdor-lipid A, facilitated by the LpxC enzyme. LpxC enzyme is the target development of antibiotics due to cofactors $\mathrm{Zn}^{2+}$. Single bulb garlic is potential herbal successor synthetic antibiotics. Alliin, Allicin, and Ajoene are contained in a single bulb garlic have antibacterial activity. This research aims predict potential of an organosulfur compounds single bulb garlic as antibacterial agents through a virtual screening method using molecular docking. Method does is to predict potential organosulfur compounds using web servers PASS and the docking ligand-interactions to figure out the target protein. The results showed, organosulfur compounds are potent antibacterial, antibiotic, and immunomodulator. Antibacterial activity of Alliin compound is shown by the best-value binding affinity-5.2 kcal/mol. Organosulfur compounds all have the same Active side controls (Ciprofloxacin and Imipenem) on LpxC enzyme. The active side is shown by the
} 
presence of the amino acid residues (Ser295, Val182, and Tyr 296) bonded with hydrogen bonding and hydrophobic interactions (Phe152, Phe181, Gly85, Phe176, Ala84, Val182, Ser180, Ile241, Leu86, Tyr296, Ser295 and Met297) between Ligand-protein target.

Keywords: LpxC enzyme; Molecular Docking; Nosocomial Infections; Organosulfur Compound; Pseudomonas aeruginosa

\section{PENDAHULUAN}

Infeksi merupakan proses invasi dan multiplikasi berbagai mikroorganisme ke dalam tubuh. Infeksi nosokomial merupakan infeksi yang dapat menyerang seseorang selama dan setelah dirawat di rumah sakit. ${ }^{1}$ Infeksi nosokomial dapat terjadi karena terdapat berbagai faktor risiko, seperti penggunaan steroid, penggunaan antibiotik, penggunaan kateter urin dan kateter vena. ${ }^{2}$ Infeksi spesifik yang terjadi pada penderita infeksi nosokomial, antara lain infeksi saluran eksresi (urinari), infeksi pada bagian yang mengalami pembedahan (operasi), infeksi peredaran darah, pneumonia, infeksi tulang dan sendi, sistem saraf pusat dan infeksi sistem kardiovaskuler. ${ }^{3}$ Infeksi nosokomial di Indonesia yang disebabkan oleh $P$. aeruginosa berkisar antara 6-16\%. ${ }^{4}$

Pseudomonas aeruginosa merupakan bakteri Gram negatif, bersifat patogen, memiliki mekanisme resisten bawaan terhadap antibiotik dan disinfektan. ${ }^{5}$ Resisten tersebut diperoleh karena bakteri ini memiliki struktur lipopolisakarida (LPS) yang terdapat pada lapisan terluar sistem membran ganda, ${ }^{6}$ dan menyebabkan efek toksik. Lipid A merupakan komponen hidrofobik pada LPS dan diketahui sangat responsibel terhadap efek toksik pada inang. Sintesis lipid A dimulai dengan sintesis $\mathrm{KdO}_{2}$-lipid $\mathrm{A}$, ${ }^{7,8}$ terjadi dalam sitoplasma dan difasilitasi oleh sembilan enzim berbeda. ${ }^{9}$ LpxC merupakan enzim yang berperan sebagai katalisator dalam proses biosintesis lipid A dan target dalam pengembangan antibiotik.

Target utama penggunaan antibiotik pengobatan infeksi nosokomial yang disebabkan oleh $P$. aeruginosa adalah berbagai macam protein dalam sel bakteri, ${ }^{10}$ namun saat ini $P$. aeruginosa memiliki resistensi sangat tinggi terhadap berbagai antibiotik. P. aeruginosa memiliki resistensi dengan kisaran antara 12-19\% terhadap antibiotik Imipenem di kawasan Jakarta dan sekitarnya. ${ }^{11}$ Penggunaan antibiotik yang tidak tepat dapat menyebabkan berbagai efek samping, antara lain rasa lemas, mual, sakit kepala, bakteri resisten, hingga kematian. ${ }^{12}$

Pengembangan antibiotik berbahan alami yang minim efek samping merupakan salah satu usaha untuk mengurangi penggunaan antibiotik sintetis yang dapat membahayakan pengguna. Bawang putih (Allium sativum) tunggal merupakan bahan alami yang secara empirik banyak digunakan oleh masyarakat untuk mengobati infeksi. Kandungan senyawa aktif dalam $A$. sativum tunggal memiliki kadar lebih tinggi dibandingkan A. sativum bersiung banyak. ${ }^{13}{ }^{14}$ Senyawa aktif dengan kadar tinggi dalam minyak $A$. sativum adalah Alliin (411,4 $\mathrm{mg} / \mathrm{mL})$, Allicin $(268,2 \mathrm{mg} / \mathrm{mL})$ dan ajoene yang dapat dibedakan menjadi E-ajoene $(101,5 \mathrm{mg} / \mathrm{mL})$ dan Z-ajoene $(251,4 \mathrm{mg} / \mathrm{mL}){ }^{13} \quad$ Berdasarkan hal itulah dilakukan penelitian potensi senyawa Alliin, Allicin, E-Ajoene dan Z-Ajoene sebagai agen antibakteri yang dapat menghambat aktivitas enzim LpxC melalui virtual screening menggunakan metode molecular docking.

\section{BAHAN DAN CARA}

Penelitian ini merupakan penelitian deskriptif kualitatif menggunakan studi literatur yang relevan, beberapa software dan web server dari program komputasi. Penelitian dilakukan pada bulan Agustus-November 2017 di Jurusan Biologi Fakultas Matematika dan Ilmu Pengetahuan Alam Universitas Negeri Malang. Rancangan penelitian dilakukan melalui prediksi potensi keempat senyawa organosulfur dan proses molecular docking antara ligan-protein target.

Langkah pertama adalah mengambil struktur 3D senyawa Alliin, Allicin, E-Ajoene dan Z-Ajoene, struktur 3D antibiotik kontrol (Imipenem dan Ciprofloxacin) dari database PubChem (https:// pubchem.ncbi.nlm.nih.gov) dalam format Sybil Data Files (*.sdf) $)^{15}$ dan struktur 3D enzim LpxC dari database Protein Data Bank atau PDB (http:// www.rcsb.org) dalam format PDB File (*.pdb). ${ }^{16}$ Mengambil canonical smile keempat senyawa organosulfur untuk prediksi potensi sebagai agen antibakteri melalui layanan online PASS SERVER (http://www.pharmaexpert.ru/passonline/). ${ }^{17}$ Struktur 3D enzim LpxC yang telah didapatkan disterilisasi menggunakan software PyMol (Python Molecular Viewer) untuk menghilangkan kandungan air dan semua ligan yang terdapat pada enzim tersebut.

Proses selanjutnya adalah melakukan molecular docking untuk mengetahui interaksi masingmasing ligan-protein target. Proses molecular docking dilakukan melalui beberapa tahap, yaitu (1) identifikasi senyawa organosulfur yang berpotensi menghambat aktivitas enzim LpxC menggunakan program Autodock Vina pada software PyRx 0.8, (2) klarifikasi posisi pengikatan hasil docking keempat senyawa organosulfur serta senyawa kontrol 
dengan enzim LpxC menggunakan software PyMol, (3) visualisasi hasil docking keempat senyawa organosulfur serta senyawa kontrol dengan enzim LpxC menggunakan software LigPlot ${ }^{+}$.

Data yang didapatkan berupa nilai probability activity (Pa) potensi keempat senyawa organosulfur (Alliin, Allicin, E-Ajoene dan Z-Ajoene), nilai afinitas pengikatan, interaksi hidrofobik dan residu asam amino yang terlibat dalam interaksi liganprotein target. Kriterian yang digunakan dalam menganalisis data pada setiap parameter berbedabeda. Kriteria yang digunakan untuk menentukan nilai $\mathrm{Pa}$ adalah (1) $\mathrm{Pa}>0,7$, senyawa yang diuj mempunyai bentuk dan aktivitas analog dengan senyawa obat, (2) 0,5 $<\mathrm{Pa}<0,7$, senyawa yang diuji memiliki bentuk yang berbeda dan kemungkinan kecil mununjukkan aktivitas seperti senyawa obat, (3) $\mathrm{Pa}<0,5$, senyawa yang diuji tidak mungkin menunjukkan aktivitas seperti senyawa obat. Apabila aktivitas ini tetap diketahui dalam eksperimen, mungkin aktivitas yang sama seperti obat memang ada dalam senyawa. ${ }^{18}$ Nilai afinitas pengikatan antara ligan-protein target yang digunakan adalah < $0 .{ }^{19}$ Residu asam amino yang dihubungkan dengan ikatan hidrogen dan interaksi hidrofobik yang terbentuk dibandingkan antara senyawa organosulfur dan senyawa kontrol pada enzim LpxC.

\section{HASIL}

Potensi Senyawa Organosulfur dalam $A$. sativum Tunggal. Senyawa organosulfur (Alliin, Allicin, E-Ajoene dan Z-Ajoene) dalam A. sativum tunggal memiliki beberapa potensi yang dapat dike-
Tabel 1. Canonical Smile Senyawa Organosulfur dari A. sativum Tunggal

\begin{tabular}{cll} 
No. & Senyawa & \multicolumn{1}{c}{ Canonical Smile } \\
\hline 1. & Alliin & $\mathrm{C}=\mathrm{CCS}(=\mathrm{O}) \mathrm{CC}(\mathrm{C}(=\mathrm{O}) \mathrm{O}) \mathrm{N}$ \\
2. & Allicin & $\mathrm{C}=\mathrm{CCSS}(=\mathrm{O}) \mathrm{CC}=\mathrm{C}$ \\
3. & E- Ajoene & $\mathrm{C}=\mathrm{CCSSC}=\mathrm{CCS}(=\mathrm{O}) \mathrm{CC}=\mathrm{C}$ \\
4. & Z-Ajoene & $\mathrm{C}=\mathrm{CCSSC}=\mathrm{CCS}(=\mathrm{O}) \mathrm{CC}=\mathrm{C}$ \\
\hline
\end{tabular}

Sumber: PubChem (2017)

tahui melalui prediksi menggunakan layanan online PASS SERVER. Potensi tersebut diprediksi dengan menggunakan canonical smile yang diperoleh dari layanan online PubChem (Tabel 1). Besarnya potensi keempat senyawa organosulfur diketahui melalui nilai Probability activity (Pa).

Berdasarkan hasil prediksi menggunakan layanan online PASS SERVER terdapat tiga potensi dari masing-masing senyawa organosulfur yang dapat digunakan sebagai landasan pencarian agen antibakteri. Ketiga potensi tersebut yaitu sebagai dengan besaran nilai Pa berbeda. Nilai Pa tertinggi ketiga potensi dari senyawa organosulfur secara berurutan yaitu (1) Alliin $(0,522)$ sebagai immunomodulator dan (2) Allicin sebagai antibakteri $(0,549)$ dan antibiotic $(0,303)$ (Tabel 2).

Virtual Screening. Virtual Screening dilakukan dengan cara menambatkan struktur 3D semua ligan (keempat senyawa organosulfur dan senyawa EAjoene dan Ciprofloxacin tidak memiliki residu asam amino. Alliin dan Z-Ajoene memiliki residu asam amino yang sama dengan Imipenem, berturut-turut yaitu Ser295 dan Val182. Alliin juga memiliki residu asam amino yang sama dengan Allicin yaitu Tyr296. Interaksi hidrofobik yang dihasilkan dari visualisasi memiliki jumlah yang berbeda di masing-masing senyawa pada enzim LpxC.

Tabel 2. Prediksi Potensi Senyawa dari A. sativum Tunggal

\begin{tabular}{|c|c|c|}
\hline Senyawa & Potensi & Nilai Pa \\
\hline \multirow[t]{3}{*}{ Alliin } & Antibakteri & 0,297 \\
\hline & Antibiotik & 0,166 \\
\hline & Immunomodulator & 0,522 \\
\hline \multirow[t]{3}{*}{ Allicin } & Antibakteri & 0,549 \\
\hline & Antibiotik & 0,303 \\
\hline & Immunomodulator & 0,364 \\
\hline \multirow[t]{3}{*}{ E-Ajoene } & Antibakteri & 0,197 \\
\hline & Antibiotik & 0,098 \\
\hline & Immunomodulator & 0,293 \\
\hline \multirow[t]{3}{*}{ Z-Ajoene } & Antibakteri & 0,197 \\
\hline & Antibiotik & 0,098 \\
\hline & Immunomodulator & 0,293 \\
\hline
\end{tabular}

Sumber: PASS SERVER (2017) 


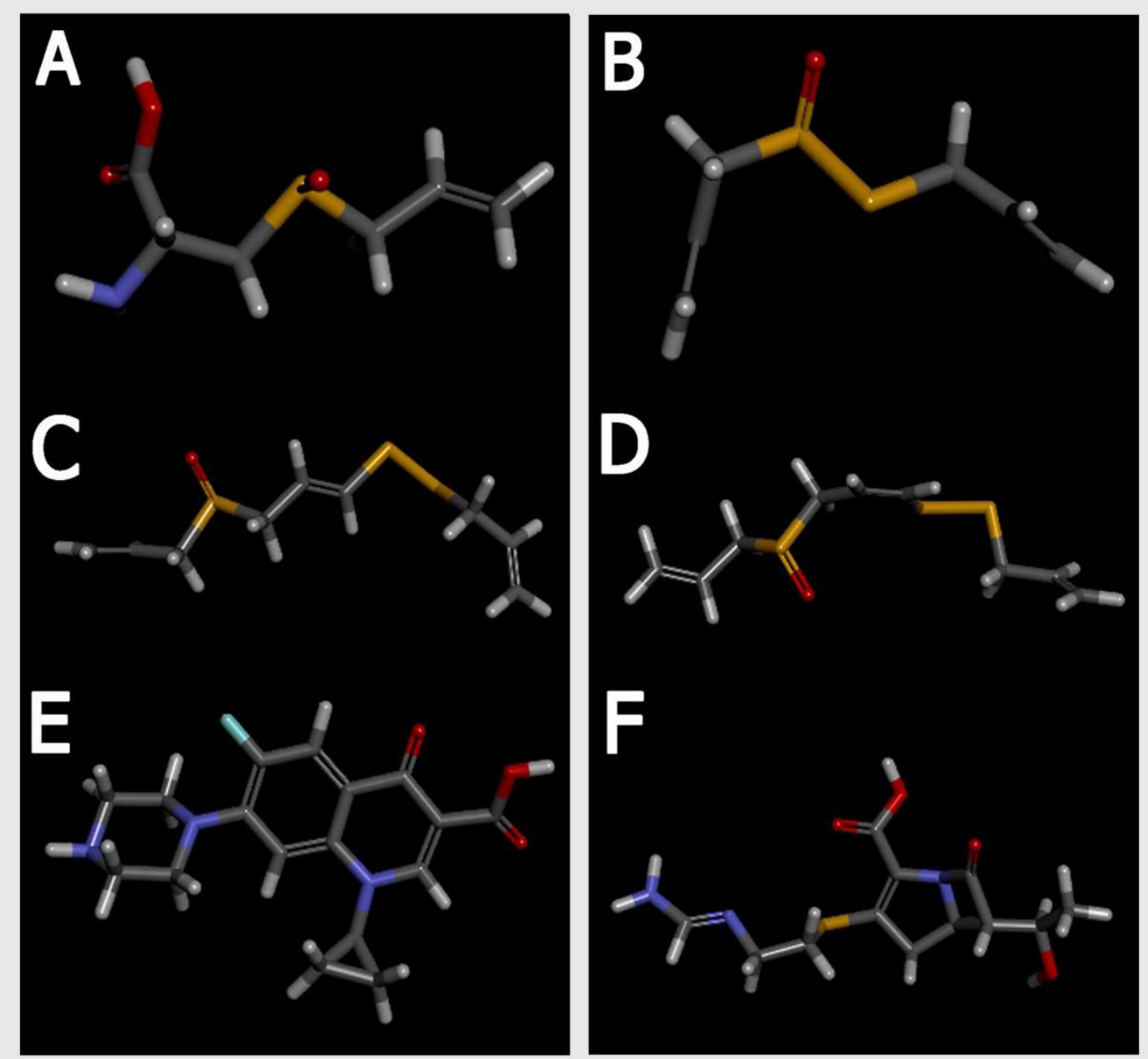

Gambar 1. Struktur 3D Senyawa Organosulfur dari A. sativum Tunggal dan Senyawa Kontrol. A. Alliin; B. Allicin; C. E- Ajoene; D. Z-Ajoene; E. Ciprofloxacin; F. Imipenem Sumber: PubChem $(2017)^{15}$
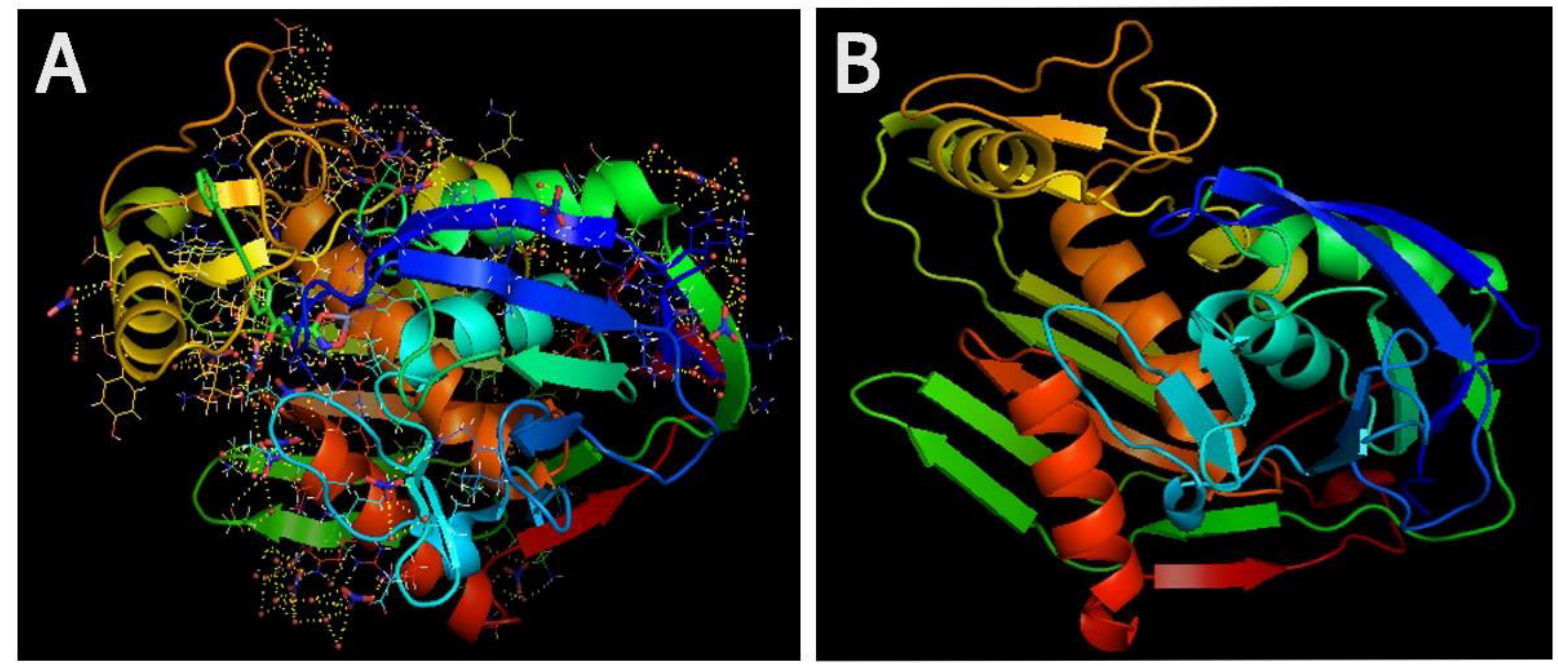

Gambar 2. Struktur 3D Enzim LpxC P. aeruginosa. A Sebelum Distrerilisasi; B Setelah Distrerilisasi. Sumber: Lee dkk (2011) ${ }^{20}$ 


\section{mutiara medika}
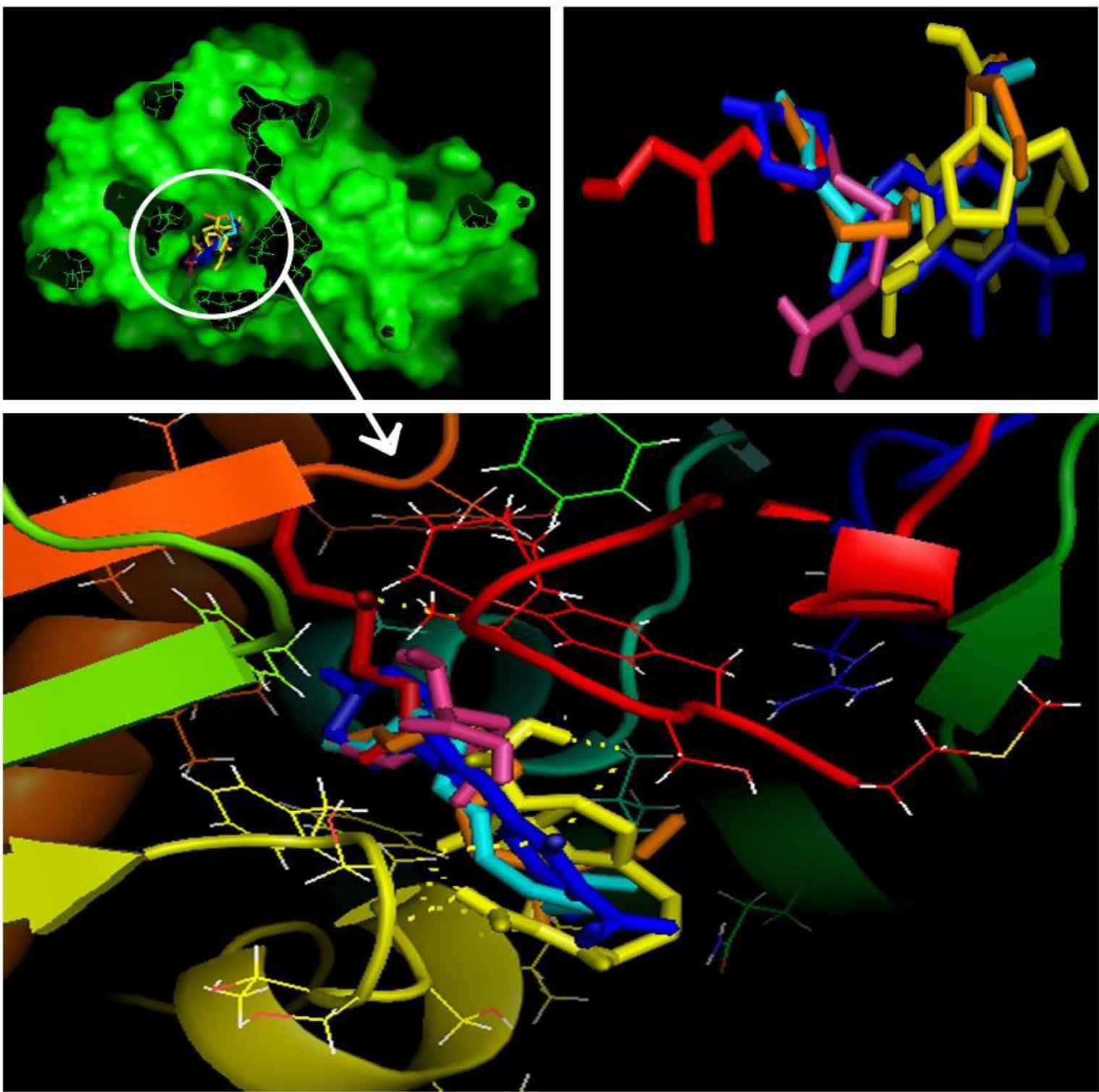

Gambar 3 A. Klarifikasi Sisi Pengikatan Senyawa Organosulfur dari A. sativum Tunggal dan Kontrol (Ciprofloxacin dan Imipenem) pada Enzim LpxC; B. Visualisasi Seluruh Senyawa yang Digunakan; C. Perbesaran Klarifikasi Sisi Pengikatan Senyawa Organosulfur dari A. sativum Tunggal dan Kontrol (Ciprofloxacin dan Imipenem) pada Enzim LpxC. 


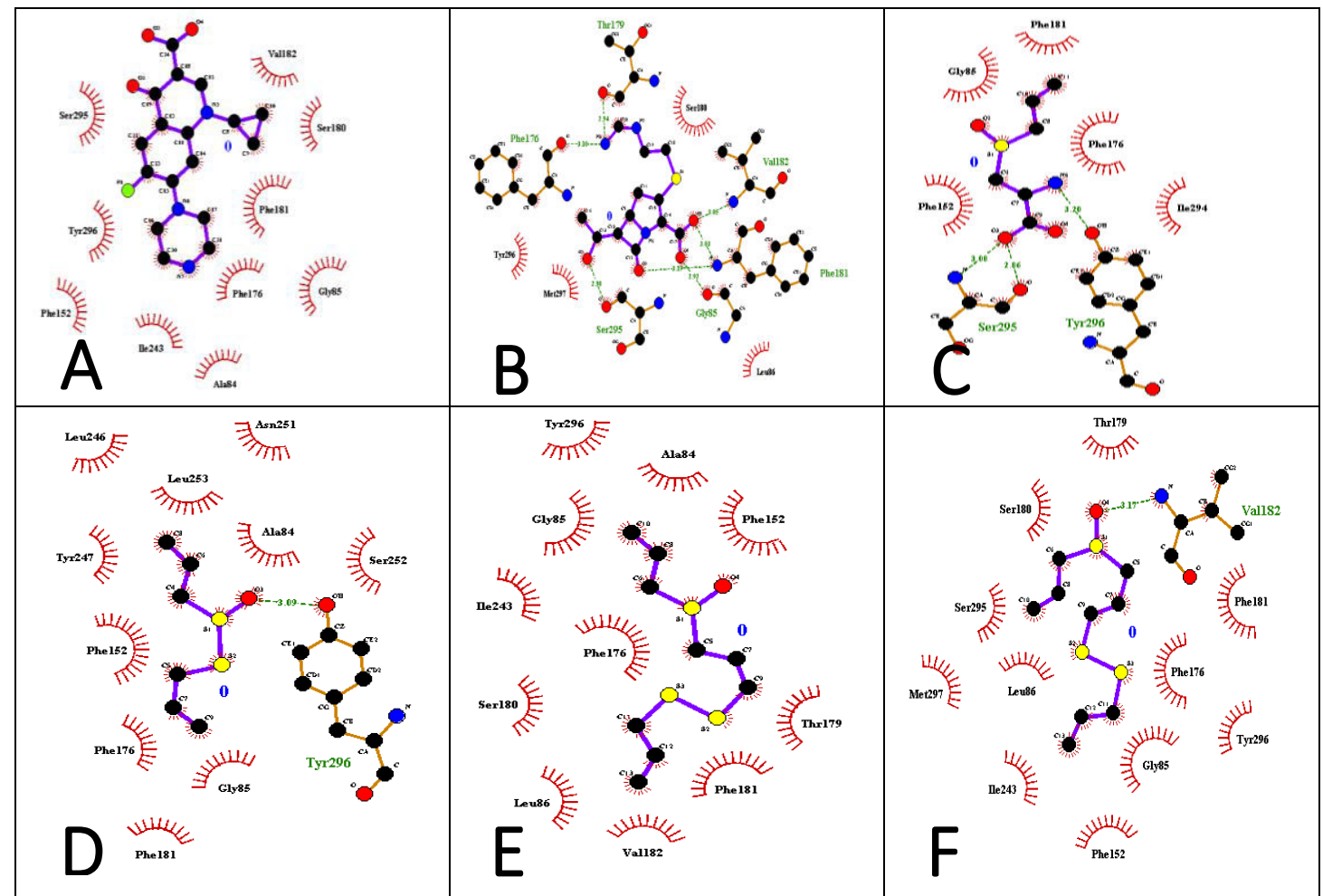

Gambar 4 Visualisasi Interaksi Sisi Pengikatan Senyawa Organosulfur dari Bawang Putih (Alliium sativum) Tunggal dan Kontrol (Ciprofloxacin dan Imipenem) pada Enzim LpxC. A. Ciprofloxacin-LpxC; B. Imipenem-LpxC; C. Alliin-LpxC; D. Allicin-LpxC; E. E-Ajoene-LpxC; D. Z-Ajoene-LpxC.

kontrol) pada struktur 3D makromolekul (enzim LpxC). Struktur 3D keempat senyawa organosulfur dan senyawa kontrol (Ciprofloxacin dan Imipenem) diperoleh dari layanan online PubChem (Gambar 1). Struktur 3D enzim LpxC melalui layanan online RCSB PDB (Gambar 2A). Struktur 3D enzim LpxC kemudian disterilisasi menggunakan software PyMol. Proses sterilisasi bertujuan untuk menghilangkan seluruh molekul air dan ligan yang terdapat pada enzim (Gambar 2B).

Proses penambatan menggunakan AutoDock Vina pada software PyRx menunjukkan bahwa senyawa kontrol (Ciprofloxacin dan Imipenem) memiliki afinitas pengikatan lebih tinggi dibandingkan senyawa organosulfur dari A. sativum tunggal (Alliin, Allicin, E-Ajoene dan Z-Ajoene) (Tabel 3).

Hasil penambatan selanjutnya diklarifikasi dan divisualisasi menggunakan dua software berbeda yaitu PyMol dan LigPlot ${ }^{+}$. Klarifikasi menggunakan software PyMol bertujuan untuk mengetahui posisi pengikatan seluruh senyawa pada enzim $L p x C$ berdasarkan struktur 3D. Visualisasi menggunakan software LigPlot $^{+}$bertujuan mengetahui interaksi antara ligan dengan makromolekul.

Hasil klarifikasi menunjukkan bahwa keempat senyawa organosulfur dan senyawa kontrol berada dalam satu sisi pengikatan yang sama pada enzim
LpxC (Gambar 3A). Enzim LpxC (Gambar 3A) ditunjukkan dengan bentuk permukaan berwarna hijau, sedangkan ligan berbentuk batang dengan warna berbeda. Warna ligan yang digunakan yaitu merah (Allicin), merah muda (Alliin), tosca (EAjoene), oranye (Z-Ajoene), biru (Ciprofloxacin) dan kuning (Imipenem) (Gambar 3B). Perbesaran hasil klarifikasi (Gambar 3A) menunjukkan dengan sangat jelas sisi pengikatan antara ligan (keempat senyawa organosulfur dan kontrol) pada enzim LpxC (Gambar 3C). Hasil visualisasi menggunakan software LigPlot ${ }^{+}$berupa residu asam amino, jumlah dan jarak ikatan hidrogen dan interaksi hidrofobik terlihat pada Gambar 4 .

Tabel 3. Hasil Molecular docking Senyawa Organosulfur dalam $A$. sativum Tunggal dan Senyawa Kontrol dengan Enzim LpxC menggunakan Software PyRx

\begin{tabular}{lc}
\multicolumn{1}{c}{ Senyawa } & Afinitas Pengikatan $(\mathrm{kkal} / \mathrm{mol})$ \\
\hline Ciprofloxacin & $-7,7$ \\
Imipenem & $-6,1$ \\
Alliin & $-5,2$ \\
E-Ajoene & $-4,8$ \\
Z-Ajoene & $-4,8$ \\
Allicin & $-4,7$ \\
\hline
\end{tabular}


Beberapa interaksi hidrofobik yang sama antara senyawa organosulfur dari $A$. sativum tunggal dengan senyawa kontrol, antara lain Phe152, Phe181, Gly85, Phe176, Ala84, Val182, Ser180, Ile241, Leu86, Tyr296, Ser295 dan Met297. Hasil visualisasi menunjukkan dari keenam senyawa, E-Ajoene dan Ciprofloxacin tidak memiliki ikatan hidrogen. Imipenem memiliki jumlah ikatan hidrogen terbanyak dibandingkan Alliin, Allicin dan Z-Ajoene dengan jarak yang berbeda-beda.

\section{DISKUSI}

Potensi Senyawa Organosulfur dalam $A$. sativum Tunggal. Prediction of Activity Spectra for Substances (PASS) merupakan aplikasi berbasis web, dirancang sebagai alat untuk mengevaluasi potensi biologis molekul organik yang dapat digunakan sebagai obat. PASS biasa digunakan untuk memeriksa aktivitas biologis suatu molekul, sebelum dilakukan sintesis kimia dan pengujian biologis. ${ }^{21}$ Besar potensi senyawa diprediksi berdasarkan perbandingan nilai Pa dengan $\mathrm{Pi}(\mathrm{Pa}: \mathrm{Pi}$ atau active, inactive ratio). Keakuratan prediksi yaitu sebesar $95 \%$ berdasarkan penilaian Leave-One-Out Cross Validation (LOO CV). ${ }^{21}$

Hasil prediksi potensi keempat senyawa organosulfur yang diperoleh dapat diinterpretasikan melalui dua kriteria yang telah disebutkan yaitu $0,5<\mathrm{Pa}<0,7$ dan $\mathrm{Pa}<0,5$. Kandungan senyawa organosulfur dalam $A$. sativum tunggal memiliki berbagai efek yang menguntungkan, antara lain dapat meningkatkan sistem imun, ${ }^{22}$ dan sebagai antimikroba. ${ }^{23}$ Senyawa organosulfur merupakan salah satu senyawa yang dapat digunakan sebagai immunomodulator. Pemberian senyawa organosulfur (Alliin, Allicin dan Ajoene) mampu mening katkan sistem pertahanan tubuh. Pemberian Alliin dapat menurunkan fosforilasi Extracellular signalregulated kinase 1 dan 2 (ERK 1/2) yang terlibat dalam peradangan pada adiposit akibat adanya induksi LPS. ${ }^{24}$

Penelitian yang dilakukan oleh Feng et al. (2012), ${ }^{25}$ mengungkapkan pemberian Allicin dapat mengurangi parasitemia dan meningkatkan kelangsungan hidup tikus Balb/C model malaria disebabkan Plasmodium yoelii. Allicin yang juga merupakan senyawa bioaktif mampu meningkatkan mediator proinflamasi seperti Interferon-Gamma (IFN-r) dan menstimulasi ekspansi Cluster of differentiation $4^{+}$ cell (sel $\mathrm{CD}^{+}$) serta makrofag. Washiya et al. (2013), ${ }^{26}$ juga mengungkapkan pengobatan menggunakan minyak $A$. sativum yang mengandung $Z$ Ajoene mampu meningkatkan kadar immuneglobulin A (IgA). Peristiwa tersebut membuktikan bahwa Z-Ajoene berpotensi menstimulasi sel B atau sekresi interleukin.

Allicin dan Ajoene juga menunjukkan aktivitas sebagai antibiotik untuk melawan bakteri Gram positif dan Gram negatif yang telah resisten terhadap antibiotik dan efektif melawan bakteri patogen. Kedua senyawa organosulfur memiliki efek antimikroba disebabkan oleh beberapa penghambatan pada bermacam sistem enzimatik tiol dependen. ${ }^{23}$ Aktivitas antimikroba dari Allicin karena adanya ikatan S-S dan S-O, akan bereaksi dengan enzim yang memiliki gugus tiol, ${ }^{23}$ dan memiliki efek yang kuat terhadap bakteri Staphylococcus aureus, diikuti dengan Escherichia coli dan $P$. aeruginosa. ${ }^{27}$ Ajoene dapat menghambat sistem komunikasi yang digunakan oleh bakteri patogen seperti $P$. aeruginosa untuk mensinkronisasi ekspresi gen spesifik yang terlibat dalam patogenesis (dikenal dengan Quorum sensing atau QS), karena memiliki potensi sebagai obat antipatogenik. ${ }^{28}$

Virtual Screening. Virtual screening merupakan penapisan senyawa obat yang dilakukan melalui komputasi dengan metode molecular docking. Molekul docking telah menjadi metode komputasi utama untuk memprediksi interaksi ligan-reseptor dan merupakan alat yang penting serta ampuh untuk melakukan perancangan obat secara rasional. ${ }^{39}$ Masalah utama yang dihadapi dalam metode docking yaitu keakuratan prediksi energi pengikatan. Keakuratan energi pengikatan memiliki implikasi besar untuk memprediksi obat baru yang efektif untuk dikembangkan. ${ }^{30}$

Hasil penelitian menunjukkan Alliin memiliki afinitas pengikatan lebih negatif dibandingkan tiga senyawa organosulfur lainnya. Afinitas pengikatan tersebut menunjukkan bahwa Alliin merupakan senyawa yang juga mampu digunakan sebagai antibakteri. Hasil ini tidak sesuai dengan pernyataan Ichsan (2009), ${ }^{31}$ yang mengungkapkan bahwa Alliin merupakan senyawa bersulfur yang belum memiliki aktivitas biologis. Kenegatifan yang lebih rendah pada fungsi penilaian melalui proses docking menunjukkan aktivitas interaksi yang lebih baik antara ligan-reseptor. ${ }^{32}$ Nilai negatif yang lebih besar pada senyawa organosulfur tidak menunjukkan aktivitas kurang baik, karena tiga dari empat senyawa memiliki interaksi beragam dan sama dengan senyawa kontrol.

Hasil visualisasi menunjukkan terdapat tiga residu asam amino yang sama (Ser295, Tyr296 dan Val182) dihubungkan pada ligan (Alliin, Allicin, ZAjoene dan Imipenem) dan enzim LpxC dengan jarak ikatan hidrogen berbeda. Ketiga residu asam amino yang dihubungkan dengan ikatan hidrogen menunjukkan bahwa senyawa organosulfur dan 
kontrol terikat dalam sisi aktif yang sama pada protein. Sisi aktif interaksi ligan-reseptor dapat diketahui dengan adanya ikatan hidrogen yang bereaksi dengan residu asam amino pada sisi aktif protein. Interaksi ini membuktikan bahwa ligan memiliki peran yang sangat penting dalam menghambat fungsi protein. ${ }^{33}$

Interaksi hidrofobik juga menentukan adanya interaksi ligan-protein yang terjadi. ${ }^{34}$ Interaksi hidrofobik merupakan interaksi molekuler lemah yang memiliki peranan penting untuk menstabilkan ligan dalam konformasi terbuka pada struktur protein. ${ }^{35}$ Jumlah rata-rata atom hidrofobik dalam obat yang dijual di pasaran adalah 16, dengan 1 sampai 2 berupa donor dan 3 sampai 4 berupa akseptor. $^{36}$ Interaksi hidrofobik dapat meningkatkan afinitas pengikatan antara ligan-reseptor serta meningkatkan aktivitas biologis dari ligan.. ${ }^{37}$ Deskripsi tersebut membuktikan pentingnya interaksi hidrofobik dalam mendesain ligan menjadi senyawa obat. Berdasarkan hal itu, maka senyawa organosulfur yang digunakan dalam penelitian dapat dikembangkan menjadi obat karena banyak interaksi hidrofobik yang terlibat dan sama dengan kontrol. Interaksi hidrofobik tersebut antara lain Phe152, Phe181, Gly85, Phe176, Ala84, Val182, Ser180, Ile241, Leu86, Tyr296, Ser295 dan Met297.

\section{SIMPULAN}

Senyawa organosulfur (Alliin, Allicin, E-Ajoene dan Z-Ajoene) dalam A. sativum tunggal berpotensi sebagai antibakteri, antibiotik dan immunomodulator yang ditunjukkan dengan besaran nilai Pa dan penelitian lain yang telah dilakukan. Potensi senyawa organosulfur sebagai agen antibakteri juga ditunjukkan dengan hasil molecular docking liganreseptor, berupa afinitas pengikatan, residu asam amino, ikatan hidrogen dan interaksi hidrofobik. Perlu adanya penelitian lebih lanjut tentang senyawa organosulfur (Alliin, Allicin, E-Ajoene dan ZAjoene) dalam $A$. sativum tunggal sebagai agen antibakteri dalam menghambat enzim LpxC. Penelitian perlu dilakukan untuk mencari profil protein yang mengalami kerusakan dan tingkat kerusakan yang terjadi pada LPS bakteri Gram negatif (terutama P. aeuginosa).

\section{UCAPAN TERIMA KASIH}

Penelitian ini merupakan penelitian payung dari Ibu Dr. Sri Rahayu Lestari, M. Si yang didanai oleh DRPM 2017 dengan nomor kontrak 3.4.8/UN32.14/LT/2017.

\section{DAFTAR PUSTAKA}

1. Inweregbu K, Dave J, Pittard A. Nosocomial Infection. Continuing Education in Anaesthesia, Critical Care Eु Pain, 2005; 5 (1): 14-17.

2. Ozer B, Akkurt CO, Duran N, Onlen Y, Savas L, Turhanoglu S. Evaluation of Nosocomial Infections and Risk Factors in Critically Ill Patients. Med Sci Monit, 2011; 17 (3): 17-22.

3. Horan TC, Andrus M, Dudeck MA. CDC/NHSN Surveillance Definition of Health Care-Associated Infection and Criteria for Specific Types of Infection in the Acute Care Setting. Am J Infect Control, 2008; 36 (5): 309-332.

4. Zulkarnain I. Buku Ajar Ilmu Penyakit Dalam: Infeksi Nosokomial. Edisi 4. Jakarta: Pusat Penerbitan Departemen Ilmu Penyakit Dalam Fakultas Kedokteran Universitas Indonesia. 2006.

5. Tamber S, Maier E, Benz R, Hancock REW. Characterization of $\mathrm{OpdH}$, a Pseudomonas aeruginosa Porin Involved in the Uptake of Tricarboxylates. J Bacteriol, 2007; 189 (3): 929. 939.

6. Madigan MT, Martinko JM, Stahl DA, Clark DP. Brock: Biology of Microorganisms. Thirteenth Edition. US of America: Pearson. 2011.

7. Raetz CRH, Whitfield C. Lipopolysaccharide endotoxins. Annu Rev Biochem, 2002; 71 (1): 635700.

8. Doerrler WT. Lipid Trafficking to the Outer Membrane of Gram-negative Bacteria. Mol Microbiol, 2006; 60 (3): 542-52.

9. Wang X, Quinn PJ. Lipopolysaccharide: Biosynthetic Pathway and Structure Modification. Prog Lipid Res, 2010; 49 (2): 97-107.

10. Phalamthodi SM, Gaikwad VJ, Ghasghase NV, Patil SS. Antibacterial Targets in Pseusomonas aeruginosa. Int J Pharm App, 2011; 2 (3): 159-164.

11. Moehario LH, Hartono TS, Wardoyo EH, Tjoa E. Trend of Antibiotiks Susceptibility of Multidrugs Resistance Pseudomonas aeruginosa in Jakarta and Surrounding Areas From 2004 to 2010. Afr J Microbiol Res, 2012; 6 (9): 2222-2229.

12. Micek ST, Lloyd AE, Ritchie DJ, Reichley RM, Fraser VJ, Kollef MH. Pseudomonas aeruginosa Bloodstream Infection: Importance of Appropriate Initial Antimicrobial Treatment. Antimicrob Agents and Chemother, 2005; 49 (4): 1306-1311.

13. Lestari SR, Rifa'i M. Daily Administration of Single Garlic Oil Extract in Mice as Sub-Chronic Toxicity Assesment. The $5^{\text {th }}$ International Conference on Biological Sciences. 2017.

14. Yoo M, Lee S, Lee S, Seog H, Shin D. Validation of High Performance Liquid Chromatography Methods for Determination of Bioactive Sulfur 
Compound in Garlic Bulbs. Food Sci. Biotechnol, 2010; 19 (6): 1619-1626.

15. PubChem. 2017. Databases Compound. (Online), (https://pubchem.ncbi.nlm.nih.gov, diakses 15 Oktober 2017).

16. RCSB. 2017. PDB: Protein Data Bank. (Online), (https://www.rcsb.org, diakses 17 Oktober 2017).

17. PASS SERVER. 2017. Way2Drug Predictive Services: Understanding Chemical-Biological Interactions. (Online), (http://www.pharmaexpert.ru/passonline/, diakses 15 Oktober 2017).

18. Lagunin A, Stepanchikova A, Filimonov D, Poroikov V. PASS: Prediction of Activity Spectra for Biologically Active Substances. Bioinformatics Applications Note, 2000; 16 (8): 747-748.

19. Atkovska K, Samsonov SA, Paszkowski-Rogacz M, Pisabarro MT. Multipose Binding in Molecular Docking. Int J Mol Sci, 2014; 15 (2); 2622-2645.

20. Lee CJ, Liang X, Chen X, Zeng D, Joo SH, Chung HS, Barb AW, Swanson SM, Nicholas RA, Li Y, Toone EJ, Raetz CR, Zhou P. Species-Specific and Inhibitor-Dependent Conformation of LpxC: Implications for Antibiotic Design. Chem Biol, 2011; 18: 38-47.

21. Parasuraman S. Prediction of Activity Spectra for Substance. J Pharmacol Pharmacother, 2011; 2 (1): 52-53.

22. Amagase H, Petesch BL, Matsuura H, Kasuga S, Itakura Y. 2001. Intake of Garlic and Its Bioactive Compounents. J Nutr, 2001; 131 (3s): 955S-962S.

23. Rehman F, Mairaj S. Antimicrobial Studies of Allicin and Ajoene. Int J Pharm Bio Sci, 2013; 4 (2): 1095-1105.

24. Quintero-Fabian S, Ortuno-Sahagun D, VazquezCarrera M, Lopes-Roa RI. Allicin, a Garlic (Allium sativum) Compound, Prevents LPS-induced Inflammation in 3T3-L1 Adpose. Mediators Inflamm, 2013; 2013 (1): 1-12.

25. Feng Y, Zhu X, Wang Q. 2012. Allicin Enhances Host Pro-Inflammatory Imune Respoonnses and Protects Against Acute Murine Malaria Infection. Malar J, 2011; 11 (1): 268.

26. Washiya Y, Nishikiwa T, Fujino T. 2013. Enhancement of Intestinal IgA Production by Ajoene in Mice. Biosci Biotechnol Biochem, 2013; 77 (11): 2298-2301.

27. Dusica PI, Vesna DN, Ljubisa BN, Mihajlo ZS. \& Ljiljana PS. Thermal Degradation, Antioxidant and Antimicrobial Activity of the Synthesized Allicin and Allicin Incorporated in Gel. 2010. Hem. Ind, 2010; 64 (2): 85-91.

28. Jakobsen TH, Gennip M, Phipps Rk, Shanmugham S, Christensen LD, Alhede M, et al. Ajoene, a Sulfur-Rich Molecule from Garlic, Inhibits Gene Controlled by Quorum Sensing.
Antimicrob Agents Chemother, 2012; 56 (5): 2314 2325.

29. Meng XY, Zhang HX, Mezei M, Cui M. Molecular Docking: A Powerful Approach for StructureBased Drug Discovery. Curr Comput Aided Drug Des, 2011; 7 (2): 146-157.

30. Elokely KM, Doerksen RJ. Docking Challenge: Protein Sampling and Molecular Docking Performance. J Chem Inf Model, 2013; 53 (8): 1934-1945.

31. Ichsan BZ. Efek Antibakteri Ekstrak Bawang Putih (Allium sativum) terhadap Pertumbuhan Streptococcus mutans Secara in Vitro. Skripsi tidak diterbitkan. Surakarta: Fakultas Kedokteran Universitas Sebelas Maret. 2009.

32. Amudha M, Rani S. In Silico Molecular Docking Studies on the Phytoconstituents of Cadaba Fruticosa (L.) Druce for Its Fertility Activity. Asian J Pharm Clin Res, 2016; 9 (2): 48-50.

33. Sahoo M, Jena L, Daf S, Kumar S. Virtual Screening for Potential Inhibitors of NS3 Protein of Zika Virus. Genomics Inform, 2016; 14 (3): 104 111.

34. Sehgal SA, Khattak NA, Mir A. Structural, Phylogenetic and Docking Studies of D-amino Acid Oxidase Activator (DAOA), a Candidate Schizophrenia Gene. Theor Biol Med Model, 2013; 10 (3): 1-13.

35. Patil R, Das S, Stanley A, Yadav L, Sudhakar A, Varma AK. Optimized Hydrophobic Interactions and Hydrogen Bonding at the Target-Ligand Interface Leads the Pathways of Drug-Designing. Plos One, 2010; 5 (8): 1-10.

36. Davis AM, Teague SJ. Hydrogen Bonding, Hydrophobic Interaction and Faiilure of the Rigid Receptor Hypothesis. Angew Chem Int Ed, 1999; 38 (6): 736-749.

37. Qian S, Waldron L, Choudhary N, Klevit RE, Chazin WJ, Patterson C. Engineering a Ubiquitin Ligase Reveals Conformational Flexibility Required for Ubiquitin Transfer. J Biol Chem, 2009; 284 (39): 26797-26802. 